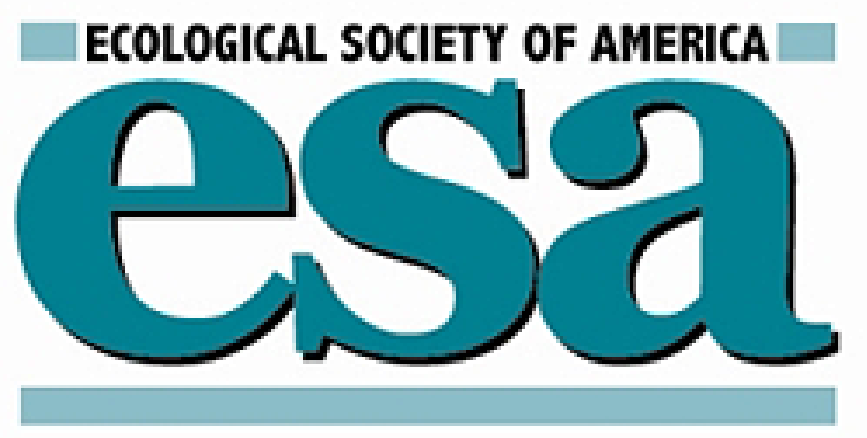

Influences of Food Availability and Predation on Survival of Kittiwakes Author(s): Daniel Oro and Robert W. Furness

Source: Ecology, Vol. 83, No. 9 (Sep., 2002), pp. 2516-2528

Published by: Ecological Society of America

Stable URL: http://www.jstor.org/stable/3071811

Accessed: 27/06/2014 06:21

Your use of the JSTOR archive indicates your acceptance of the Terms \& Conditions of Use, available at http://www.jstor.org/page/info/about/policies/terms.jsp

JSTOR is a not-for-profit service that helps scholars, researchers, and students discover, use, and build upon a wide range of content in a trusted digital archive. We use information technology and tools to increase productivity and facilitate new forms of scholarship. For more information about JSTOR, please contact support@ jstor.org. 


\title{
INFLUENCES OF FOOD AVAILABILITY AND PREDATION ON SURVIVAL OF KITTIWAKES
}

\author{
DANIEL ORO ${ }^{1,3}$ AND RoBert W. FURNESS ${ }^{2}$ \\ 'Institut Mediterrani d'Estudis Avançats (IMEDEA), CSIC-UIB, 07190 Esporles, Mallorca, Spain, and \\ Departamento Biologia Animal, Vertebrats, Universitat de Barcelona, Diagonal 645, 08028 Barcelona, Spain \\ ${ }^{2}$ Ornithology Group, Institute of Biomedical and Life Sciences, Graham Kerr Building, \\ University of Glasgow, Glasgow G12 8QQ, UK
}

\begin{abstract}
Life history theory predicts a trade-off between current reproduction and survival to maximize fitness. In long-lived seabirds, one might expect adults not to jeopardize survival by excessive reproductive investment when environmental conditions for breeding are adverse. Some environmental factors have reduced the fecundity of Blacklegged Kittiwakes (Rissa tridactyla) breeding in Shetland, UK, a metapopulation that has declined substantially during the last two decades. Two hypotheses are proposed to explain this decrease: (1) reduced availability of sandeels (the main prey for kittiwakes), which has occurred since the late 1980s; and (2) increased predation by Great Skuas (Catharacta $s k u a$ ), the main predator of kittiwakes. Detailed data on food supply (sandeel stock size, by age groups), kittiwake body condition and breeding success, and diet and productivity of Great Skuas allowed us to assess the influence of each of these factors on adult kittiwake survival from 1986 through 1997. Capture-recapture models were constructed to examine correlations between local adult survival rate and environmental parameters. Body condition at the end of the breeding season and availability of 0 -group (juveniles $\leq 1 \mathrm{yr}$ old) sandeels positively influenced adult survival, whereas survival was lower when Great Skua productivity was high. Adult survival varied greatly during the study, from $0.53 \pm 0.04$ to $0.98 \pm 0.01$ (mean $\pm 1 \mathrm{SD}$ ), and was independent of sex. Both hypotheses were supported. Contrary to predictions of life history theory, kittiwakes did not refrain from breeding in years of poor food supply or high predator activity to buffer their survival at the cost of not rearing chicks. Although 0 -group sandeel availability affected breeding success of kittiwakes, its influence on adult survival was also significant. The discovery that food supply affects adult survival rate has important implications for fisheries management to minimize impacts on seabirds.
\end{abstract}

Key words: Ammodytes marinus; body condition; Black-legged Kittiwake; Catharacta skua; cost of reproduction; food availability; Great Skua; life history; predation; Rissa tridactyla; sandeel; SURGE.

\section{INTRODUCTION}

Life history theory envisages trade-offs between components of fitness, such as survival and reproductive investment (Roff 1992, Stearns 1992, McNamara and Houston 1996). Long-lived birds, such as most seabirds (Furness and Monaghan 1987), may be expected to respond to adverse environmental conditions (such as reductions in food abundance, increased predation, or bad weather) by reducing their investment in current reproduction in order to increase residual reproductive value and maximize lifetime reproductive success (Monaghan et al. 1989, Montevecchi 1993, Sæther et al. 1993, Pyle et al. 1997, Oro and Pradel 2000). Based on such life history considerations, Cairns (1987) proposed a model of seabird responses to food supply in which slight reductions affect breeding adult activity budgets and diet selection, but not

Manuscript received 12 February 2001; revised 30 October 2001; accepted 30 October 2001; final version received 7 January 2002.

${ }^{3}$ E-mail: d.oro@uib.es breeding success or adult survival rate. In his model, moderate reductions would also affect chick growth and breeding success, but only severe reductions in food supply would cause a reduction in adult survival rates, by which time effects on breeding success would be catastrophic. Monaghan et al. (1992) proposed that Arctic terns Sterna paradisaea followed such a pattern of reproductive investment, abandoning current breeding effort when body condition fell below a threshold that might begin to affect survival prospects of the parents. Similarly, Wernham and Bryant (1998) showed inter-year reproductive costs for Atlantic Puffins Fratercula arctica, supporting the hypothesis that such long-lived birds reduce the "quality" of their offspring or abandon a breeding attempt rather than compromise their survival and future opportunities to reproduce. A few studies have validated a corollary of this model, showing that the demography of long-lived birds may tend to be driven by variations in reproductive output across years, or by the balance between immigration and emigration, because adult survival rates would be 
expected to remain rather constant and not vary with food supply (Pons and Migot 1995, Oro et al. 1999). According to predictions of life history theory, several recent experimental studies in which reproductive effort of adults was manipulated by adjustment of brood sizes have shown that, in Black-legged Kittiwakes Rissa tridactyla, adult survival rate is considerably reduced in birds that invest more in current reproduction (Erikstad et al. 1995, Jakobsen et al. 1995, Golet et al. 1998).

Shetland, an archipelago in the northwestern North Sea, holds large breeding populations of many species of seabirds that feed predominantly on sandeels $\mathrm{Am}$ modytes marinus during the breeding season (Furness 1990). During the late 1980s, the population of sandeels at Shetland decreased, reducing breeding success in many species of seabirds for several years (Monaghan et al. 1989, Hamer et al. 1991, 1993, Phillips et al. 1996, Ratcliffe et al. 1998). One of the seabirds with the most severely reduced breeding success was the Black-legged Kittiwake (Walsh et al. 1991, 1992, 1993, 1994, 1995a, Danchin 1992, Thompson et al. 1996, 1997, 1998), but accompanying patterns in adult survival of Shetland kittiwakes have not been reported. In this paper, we analyze data on the survival rate of breeding adult Black-legged Kittiwakes at a colony in Shetland (i.e., local survival), and investigate factors affecting the variations in annual survival, mainly related to food availability and predation rate. There are exceptionally detailed data from this area on food supply (sandeel stock size), Black-legged Kittiwake breeding success, breeding population size, and diet, as well as productivity of the main kittiwake's predators, Great Skuas (Catharacta skua), body condition and adult survival rate over this period of low and recovering food abundance. These data allow us to test the prediction of life history theory about the trade-off between fecundity and survival: for a long-lived bird such as the Black-legged Kittiwake, adult survival would remain rather constant regardless of environmental conditions, whereas reproduction would be more successful when conditions were favorable.

\section{STUdy AREA}

Data on sandeel abundance, Black-legged Kittiwake breeding numbers, and average annual breeding success are for the whole of Shetland, UK $\left(60^{\circ} \mathrm{N}, 1^{\circ} \mathrm{W}\right)$, an archipelago on the European continental shelf between the northern North Sea and the Atlantic Ocean. Data on kittiwake body condition and annual survival rates of breeding adults, as well as breeding success of Great Skuas, are from a single colony in Shetland, on the island of Foula. Foula has several separate colonies of Black-legged Kittiwakes, but the study colony (Noup) was particularly convenient: low on a large cliff under an overhang, with a rock shelf below the colony allowing easy access to nests. Although this study colony was selected for ease of access and capture of adult
Black-legged Kittiwakes, it became evident that it was one of the more successful kittiwake colonies in Shetland during the study period (1986-1997), showing consistently higher than average breeding success and a slower rate of decline in breeding numbers than at most other sites.

\section{METHODS \\ Compilation of Shetland data}

Data on the annual breeding success of Black-legged Kittiwakes at sample plots in colonies throughout Shetland were obtained from the annual reports on breeding success of seabirds at monitoring sites in Britain and Ireland (Walsh et al. 1991, 1992, 1993, 1994, 1995a, Thompson et al. 1996, 1997, 1998). These data come from $\sim 2500-3000$ nests monitored per year at $\sim 9-10$ colonies, of which Foula is one. We included this measure of breeding success as well as that derived from Foula alone, because the Foula sample was from only $\sim 100$ nests at two sites and so showed greater chance variation than did the larger sample for Shetland. However, the two data sets were closely correlated.

Estimates of sandeel abundance for the whole of Shetland were obtained from ICES (1997, 1998), and were expressed as mean numbers of 0 -group and $1+$ ( $\geq 1$-yr-old) sandeels caught per 30-min tow during June (1987 and 1995 data were back-calculated from VPA (Virtual Population Analysis) in ICES [1998]). These age categories were kept separate because there is evidence that breeding success of Black-legged Kittiwakes is higher when abundance of $1+$ sandeels is high, but the abundance of 0 -group sandeels in the whole North Sea shows a negative correlation with the abundance of older fish (Furness 1999), possibly as a result of competition reducing juvenile survival when abundance of older sandeels is high. The fact that Black-legged Kittiwake breeding success correlates with this measure of the abundance of $1+$ sandeels (obtained by research fishing at various sites around Shetland) suggests that this is a valid measure of sandeel availability to Black-legged Kittiwakes across years.

\section{Fieldwork at Foula}

Data were collected every year from 1986 to 1997. The breeding productivity of Black-legged Kittiwakes at Foula was monitored using standard methods employed throughout Britain and Ireland (Walsh et al. $1995 b$ ), for samples of 100-150 nests at sites in the north (kittiwakes Haa and Logat) and south (Noup) of Foula. Productivity of Great Skuas was monitored using the standard method for that species (Walsh et al. $1995 \mathrm{~b}$ ) for samples of 50-100 territories in the northeast of Foula. The Great Skua chick diet was quantified by collecting and identifying voluntary regurgitates from chicks handled for banding in 1-20 July each year. Numbers of chicks banded varied from 400 to 2000 in 
different years, and numbers of regurgitates varied from 10 to 80 . Each regurgitate was almost invariably of a single food type, so diet was expressed as the percentage of regurgitates consisting of sandeels.

The Noup colony of kittiwakes was visited 1-3 times within a few days of 10 July each year (when chicks were mostly about half grown) in order to capture adults from nests. Due to total breeding failure in 1988, no adults were caught. In all other years, adults were caught from below the cliff, using an $8 \mathrm{~m}$ long carbon fiber fishing pole with a nylon running noose that was slipped over the head of an adult standing on its nest. This procedure was highly effective and caused little disturbance to birds on neighboring nests, so that a high percentage of adults at the colony could be captured. Numbers caught were constrained by the time available for this work and, to some extent, by prevailing weather conditions, but we aimed each year to sample as uniformly as practical from all parts of the colony. The average catch in the 11 seasons when adults were caught was 82 adults from $\sim 120-130$ nests. It was usually impossible to see if a bird was banded before it was noosed because the birds were standing on projecting nests. However, captures were biased toward birds that were breeding successfully (not all failed breeders attended the nest and those present often flew off as the noose was presented toward them). Among successful breeders, there was probably a slight bias toward catching birds that were more determined to remain on the nest when the noose approached. However, in our use of SURGE and RELEASE to estimate survival and recapture probabilities, no adverse effects of nonrandom capture on survival estimates were evident (e.g., trap dependence, transient effects; Pradel et al. 1997). We conclude that these biases were inconsequential and that assumptions of capture-recapture models were met (see Lebreton et al. 1992). We recorded wing length (maximum chord), primary molt, head length, bill length and depth, and body mass, and identified any food regurgitated. All measurements were taken by R. W. Furness. Band numbers were recorded or unbanded birds were fitted with a new metal band. Before release, a small spot of dye was put onto the forehead of the adult; birds invariably returned to their nest within a minute or two of release, so it was necessary to mark caught birds to avoid multiple captures. Because birds were not color-banded, identification of surviving birds was only made for those individuals that were recaptured and had their band numbers read. No negative effects of capture (nest desertion, chick death, or injury to adults) were detected in the year of capture or subsequently.

Measures of head length and wing length were used to sex adults. Coulson et al. (1983) present criteria to sex Black-legged Kittiwakes and other gulls in "Britain," based on head length, but their equation for Black-legged Kittiwakes, based on data collected predominantly from a colony in northeast England, is in- appropriate in Shetland due to clinal variation in size in this species (Sluys 1982, Barrett et al. 1985). Therefore, we plotted histograms of head and of wing length and selected the low point between the bimodal distributions as measures to discriminate between sexes. In both cases, this produced plots with some birds assigned as females and some as males. In the cases in which a bird was classified differently according to wing or head, the individual was classified as of unknown sex. We also used cluster analysis to examine the numbers of birds falling into the two groups based on head and wing data.

\section{Statistical methods}

We estimated survival probabilities and tested biological hypotheses using recent developments of capture-recapture methods (Lebreton et al. 1992). Data were analyzed in two steps. First, we looked for a general model fitting the data, the Cormack-Jolly-Seber (CJS) model, $\left(\phi_{t}, p_{t}\right)$, where $\phi$ is the local survival rate and $p$ is recapture probability, and both parameters were dependent on time $(t)$. The goodness of fit of the model was assessed using the program RELEASE (e.g., Burnham et al. 1987). The component tests within TEST2 $\left(\chi^{2}=13.0, \mathrm{df}=19, P=0.84\right)$ and TEST3 $\left(\chi^{2}\right.$ $=29.6, \mathrm{df}=21, P=0.10)$ showed that the initial CJS model fitted the data.

The second step started from the CJS model, from which we constructed additional models. These models were fitted by the maximum likelihood method using the program SURGE 4.2 (Cooch et al. 1996). Models were then constrained by ecological hypotheses based on factors that, in our view, could affect survival or recapture probabilities (see Table 1). The possibility that some factors affected survival rates was also considered in the models as a logit-linear constraint (Lebreton et al. 1992). This constraint was expressed in the framework of generalized linear models (McCullagh and Nelder 1989) as $\phi_{t}=f\left(a_{0}+\sum a_{i} x_{i t}\right)$. The factors $\left(x_{i t}\right)$ considered were: mean body mass of adults toward the end of the breeding season $(m)$, sandeel availability (either 0 -group $(s 0)$ or $1+$ group $(s 1)$ ), breeding success of Black-legged Kittiwakes at the colony $(k 1)$, breeding success of Black-legged Kittiwakes in Shetland $(k 2)$, percentage of sandeel in chick regurgitates of Great Skuas $(b 1)$ and their breeding success (b2) (see Table 2). These factors were also considered for the modeling of recapture probabilities, which is crucial to avoid biases in survival estimation and interpretation of biological hypotheses (Clobert 1995, Boulinier et al. 1997). Different models included variation in the parameters as a function of year and sex $(s)$ of individuals. Recapture probability for 1988 , when the colony was not monitored because of the extremely negative environmental conditions, was fixed to 0 . Thus, survival $\phi_{88}$ for the period 1987-1988 could not be estimated, and only the product $\left(\phi_{88} \phi_{89}\right)$ was estimated by the models. Unsexed birds were con- 
TABLE 1. Summary of the different $(\phi, p)$ models built with SURGE to estimate survival probability $(\phi)$ and recapture probability $(p)$.

\begin{tabular}{cl}
\hline \hline $\begin{array}{c}\text { Model } \\
\text { notation }\end{array}$ & \multicolumn{1}{c}{ Biological hypothesis } \\
\hline Modeling $\phi$ & \\
$\phi_{t}$ & survival is time dependent \\
$\phi_{s}$ & survival is dependent on sex \\
$\phi_{m}$ & constant survival \\
$\phi_{m}$ & survival is dependent on mean body mass of adults \\
$\phi_{k 1}$ & survival is dependent on kittiwake productivity in Shetland \\
$\phi_{f 0}$ & survival is dependent on kittiwake productivity in Foula \\
$\phi_{f 1}$ & survival is dependent on availability of 0-group sandeel \\
$\phi_{b 1}$ & survival is dependent on availability of 1 + group sandeel \\
$\phi_{b 2}$ & survival is dependent on the percentage of sandeels in Great Skua diet \\
Modeling $p$ & \\
$p_{t}$ & recapture is time dependent \\
$p_{s}$ & recapture is sex dependent \\
$p_{e}$ & recapture is dependent on effort of recapture (no. adults caught) \\
\hline
\end{tabular}

sidered as a mixture in roughly equal proportions of males and females. This was achieved by coding the covariate sex as 0 for females, 1 for males, and 0.5 for individuals of unknown sex (see also Oro et al. 1999). This ensures that, when using the covariate sex in the model, the recapture probability of unsexed individuals will be approximately equal to the mean of the capture probabilities of males and females (exactly on a logit scale). To estimate recapture probability, several models were also constructed to allow for the different recapture effort made each year. We assumed that the best measure of the amount of effort put into retrapping Black-legged Kittiwakes each year was the total number of adults caught, because catching was very easy and processing birds took a fairly standard amount of time. When two factors entered a model with their interaction, they were separated by an asterisk in the model notation. When the interaction was not present, a plus sign was used instead. For instance, $\left(\phi_{s^{*} t}, p_{s^{*}}\right)$ designates a model in which survival and recapture probabilities varied with sex and time, each combination of the two factors being independent. The significance of the factors considered and of their interactions was assessed by comparing models with or without the effects tested. Different methods for selecting among models have been compared in a series of recent papers (e.g., Anderson et al. 1994, Burnham et al. 1994, 1995). Here, following recommendations of these authors, selection of models was made on the basis of the Akaike's Information Criterion (AIC), the model with the smallest AIC value being selected and accepted as the most parsimonious model (see also Lebreton et al. 1992). AIC is defined as AIC = DEV + $2 n_{\mathrm{p}}$, where DEV represents the deviance $(-2 \ln (\hat{\mathrm{L}}), \hat{\mathrm{L}}$

TABLE 2. Values for the study period of the factors introduced in the models as a logit-linear constraint to assess their potential influence on survival rates of Black-legged Kittiwakes in Foula.

\begin{tabular}{|c|c|c|c|c|c|c|c|}
\hline \multirow[b]{3}{*}{ Year } & \multicolumn{3}{|c|}{ Black-legged Kittiwakes } & & & \multicolumn{2}{|c|}{ Great Skuas } \\
\hline & \multirow[b]{2}{*}{$\begin{array}{c}\text { Mean adult mass, } \\
\mathrm{g}(n) \dagger\end{array}$} & \multicolumn{2}{|c|}{ Productivity $\ddagger$} & \multicolumn{2}{|c|}{ Sandeels§ } & \multirow{2}{*}{$\begin{array}{l}\text { Sandeel in } \\
\text { chick } \\
\text { regurgi- } \\
\text { tates }(\%) \dagger\end{array}$} & \multirow[b]{2}{*}{$\begin{array}{l}\text { Productivity } \\
\text { at Foulat }\end{array}$} \\
\hline & & $\begin{array}{l}\text { Shetland } \\
\text { (JNCC } \\
\text { reports)\| }\end{array}$ & Foulat & $\begin{array}{l}\text { 0-group } \\
\text { sandeel abundance } \\
\text { (ICES 1998) }\end{array}$ & $\begin{array}{l}1+\text { sandeel } \\
\text { abundance } \\
(\text { ICES 1998) }\end{array}$ & & \\
\hline 1986 & $380 \quad(28)$ & 0.79 & 0.88 & 681869 & 87934 & 65 & 1.0 \\
\hline 1987 & $395 \quad(35)$ & 0.52 & 0.30 & 5282 & 145918 & 55 & 0.7 \\
\hline 1988 & & 0.06 & 0.00 & 73371 & 22212 & 5 & 0.1 \\
\hline 1989 & $354(135)$ & 0.18 & 0.31 & 813752 & 20314 & 14 & 0.2 \\
\hline 1990 & 347 (134) & 0.15 & 0.50 & 90148 & 38886 & 20 & 0.4 \\
\hline 1991 & $380(141)$ & 0.59 & 0.75 & 1009024 & 14449 & 28 & 0.6 \\
\hline 1992 & $366(112)$ & 0.90 & 1.39 & 199301 & 467753 & 29 & 0.4 \\
\hline 1993 & $325 \quad(23)$ & 0.70 & 0.92 & 635331 & 94138 & 28 & 0.5 \\
\hline 1994 & $380 \quad(80)$ & 0.75 & 1.07 & 98653 & 194423 & 35 & 0.9 \\
\hline 1995 & $(74)$ & 0.54 & 0.92 & 135624 & 65400 & 73 & 1.1 \\
\hline 1996 & $(50)$ & 0.61 & 0.72 & 589368 & 40573 & 55 & 1.1 \\
\hline 1997 & $(30)$ & 0.28 & 1.07 & no data & no data & 60 & 1.0 \\
\hline
\end{tabular}

$\dagger$ This study.

$¥$ Productivity is expressed as mean number of chicks per pair.

$\S$ Sandeel availability is expressed as sandeel catch of fish (age 0 or $1+$ ) in 30 -min tow in Shetland waters.

|| JNCC, Joint Nature Conservation Commission. 
TABLE 3. Partial correlation coefficients (and $P$ values in parentheses) controlling for year among the environmental variables considered (see also Table 2) in the several models tested to estimate survival and recapture probabilities.

\begin{tabular}{|c|c|c|c|c|c|c|}
\hline \multirow[b]{2}{*}{ Variables } & \multicolumn{2}{|c|}{ Kittiwake productivity } & \multirow{2}{*}{$\begin{array}{c}\text { 0-group } \\
\text { sandeel } \\
\text { abundance }\end{array}$} & \multirow{2}{*}{$\begin{array}{l}1+\text { sandeel } \\
\text { abundance }\end{array}$} & \multirow{2}{*}{$\begin{array}{c}\text { Sandeel in } \\
\text { skua chick } \\
\text { regurgitaes } \\
(\%)\end{array}$} & \multirow{2}{*}{$\begin{array}{c}\text { Skua } \\
\text { productivity }\end{array}$} \\
\hline & Shetland & Foula & & & & \\
\hline Kittiwake adult mass & $\begin{array}{c}0.264 \\
(0.462)\end{array}$ & $\begin{array}{c}-0.098 \\
(0.775)\end{array}$ & $\begin{array}{c}-0.192 \\
(0.596)\end{array}$ & $\begin{array}{c}0.100 \\
(0.789)\end{array}$ & $\begin{array}{c}0.549 \\
(0.100)\end{array}$ & $\begin{array}{c}0.625 \\
(0.054)\end{array}$ \\
\hline Kittiwake productivity, Shetland & & $\begin{array}{l}0.875 \\
(0.001) * *\end{array}$ & $\begin{array}{c}0.165 \\
(0.649)\end{array}$ & $\begin{array}{c}0.632 \\
(0.048) *\end{array}$ & $\begin{array}{c}0.511 \\
(0.132)\end{array}$ & $\begin{array}{c}0.519 \\
(0.125)\end{array}$ \\
\hline Kittiwake productivity, Foula & & & $\begin{array}{c}0.102 \\
(0.778)\end{array}$ & $\begin{array}{c}0.717 \\
(0.020)^{*}\end{array}$ & $\begin{array}{c}0.314 \\
(0.378)\end{array}$ & $\begin{array}{c}0.300 \\
(0.399)\end{array}$ \\
\hline 0-group sandeel abundance & & & & $\begin{array}{c}-0.358 \\
(0.310)\end{array}$ & $\begin{array}{c}-0.057 \\
(0.876)\end{array}$ & $\begin{array}{c}0.026 \\
(0.943)\end{array}$ \\
\hline $1+$ sandeel abundance & & & & & $\begin{array}{c}0.018 \\
(0.961)\end{array}$ & $\begin{array}{c}-0.089 \\
(0.807)\end{array}$ \\
\hline Sandeel $(\%)$ in skua chick regurgitates & & & & & & $\begin{array}{c}0.934 \\
(0.000)^{* *}\end{array}$ \\
\hline
\end{tabular}

$* P<0.05 ; * * P<0.01 ;$ two-tailed tests.

is the maximum likelihood) of the model, and $n_{\mathrm{p}}$, is the number of separately estimable parameters in the model. Following Anderson et al. (1994), the value of 2 was the threshold below which two models were considered to be statistically equivalent.

\section{RESULTS}

\section{Body measures of Black-legged Kittiwakes}

For 472 Black-legged Kittiwakes measured at least once, head length showed modes at $88 \mathrm{~mm}$ and $92 \mathrm{~mm}$, with a minimum between these modes at $90 \mathrm{~mm}$. Wing length showed modes at $310 \mathrm{~mm}$ and $320 \mathrm{~mm}$, with a minimum between modes at $315 \mathrm{~mm}$. Cluster analysis assigned 164 birds to the smaller mode, considered females in the analysis (mean head length $88.68 \mathrm{~mm}$, mean wing length $308.2 \mathrm{~mm}$ ), and 138 birds to the larger mode, considered males in the analysis (mean head length $91.94 \mathrm{~mm}$, mean wing length $320.5 \mathrm{~mm}$ ). We considered 170 birds classified between the smaller and the larger mode to be of unknown sex.

\section{Environmental and demographic variables}

Data on breeding success and mean body mass of adult Black-legged Kittiwakes in Shetland, at Foula, sandeel abundance (separately for 0 - and $1+$ groups), Great Skua diet and breeding success (i.e., productivity) are summarized in Table 2. All parameters showed considerable variation among years. In every case, the range exceeded an order of magnitude; the scope for detecting correlations with adult survival rate is considerable. Some of these variables showed some significant correlations among them (Table 3), such as those between the percentage of sandeel in Great Skua chick regurgitates and their productivity, or between the $1+$ sandeel abundance and kittiwake productivity both at Foula and Shetland.

\section{Survival and recapture estimates}

Reducing the number of parameters.-Simple models taking account of the effects of sex and time on both survival and recapture probabilities were first assessed to reduce the number of parameters by eliminating nonsignificant sex effects or interactions. The possible effect of capture effort on recapture probabilities was also assessed. In a first approach, sex was not significant for survival or for recapture rates. Including capture effort did not improve the fit of the model (Table 4). The more general model $\left(\phi_{t}, p_{t}\right)$ was thus retained.

Effects of environmental factors on survival.-Although some of the environmental factors considered in the analysis may have similar effects on survival, we first introduced all of the factors as additive effects to assess their relative contribution to survival probabilities. From the model $\left(\phi_{t}, p_{t}\right)$, we kept recapture probabilities depending only on time. We retained provisionally the model $\left(\left[\phi_{m+s 0+b 2}, p_{t}\right]\right.$; see Table 5$)$, in which survival was positively associated with body mass of adults and with 0 -group sandeel availability, and was negatively associated with Great Skua productivity. All three effects were significant because the $95 \%$ confidence intervals of the slopes did not include the 0 value (Table 6). We reintroduced the effect of sex on this model to be sure that sex did not affect survival after considering these environmental factors. Although sex could have a significant effect interacting with mean body mass of adults, we kept the previous selected model because it still showed the lowest AIC value (Table 7). Furthermore, there was no biological evidence to include sex differences in the model that was finally selected, because breeding effort seems similar for both sexes (e.g., Cam et al. 1998, Coulson and Strowger 1999).

Finally, we tested the hypothesis that the environmental factors affecting survival in the retained model $\left(\phi_{m+s 0+b 2}, p_{t}\right)$ were not affecting survival directly, but were influencing the recapture rate (i.e., the breeding probability) in the following year. The different models tested did not show any improvement of their fit from the previously retained model (Table 8 ). Thus, we re- 
TABLE 4. Assessment of the statistical significance of sex from the initial model $\left(\phi_{t}, p_{t}\right)$. The effect of capture effort on recapture probabilities was also assessed.

\begin{tabular}{|c|c|c|c|c|}
\hline Model & $n_{\mathrm{p}}$ & DEV & AIC & Hypothesis tested \\
\hline$\left(\phi_{s^{*}}, p_{s^{*} t}\right)$ & 57 & 1542.2 & 1656.2 & Effects of time and sex on survival and recapture probabilities \\
\hline$\left(\phi_{s+t}, p_{t^{*} s}\right)$ & 40 & 1553.8 & 1633.8 & $\begin{array}{l}\text { Additive effects of time and sex on survival; recapture depending on time and } \\
\text { sex }\end{array}$ \\
\hline$\left(\phi_{s^{*}}, p_{t}\right)$ & 39 & 1557.5 & 1635.5 & Effects of time and sex on survival; recapture depending on time \\
\hline$\left(\phi_{t}, p_{s_{*}}\right)$ & 39 & 1553.8 & 1631.8 & Effects of time on survival; recapture depending on sex and time \\
\hline$\left(\phi_{s^{*}}, p_{s^{*}}\right)$ & 36 & 1587.8 & 1659.8 & $\begin{array}{l}\text { Effects of time and sex on survival; recapture depending on sex and capture } \\
\text { effort }\end{array}$ \\
\hline$\left(\phi_{s * t}, p_{s}\right)$ & 33 & 1579.1 & 1645.1 & Effects of time and sex on survival; recapture depending only on sex \\
\hline$\left(\phi_{s}, p_{t}\right)$ & 33 & 1569.1 & 1635.1 & Effects of sex on survival; recapture depending on time \\
\hline$\left(\phi_{s_{t}^{*}}, p_{e}\right)$ & 31 & 1595.4 & 1657.4 & Effects of time and sex on survival; recapture depending on recapture effort \\
\hline$\left(\phi_{s^{*}}, p\right)$ & 31 & 1611.5 & 1673.5 & Effects of time and sex on survival; constant recapture probabilities \\
\hline$\left(\phi_{t}, p_{t}\right)$ & 19 & 1580.8 & 1618.8 & Effects of time on survival and recapture probabilities \\
\hline$\left(\phi_{t}, p\right)$ & 10 & 1636.6 & 1656.6 & Survival varies with time; constant recapture probabilities \\
\hline$\left(\phi, p_{t}\right)$ & 10 & 1604.0 & 1624.0 & Constant survival; recapture probabilities varying with time \\
\hline$\left(\phi_{s}, p_{s}\right)$ & 6 & 1667.7 & 1679.7 & Effects of sex on survival and recapture probabilities \\
\hline$(\phi, p)$ & 2 & 1669.6 & 1700.6 & Constant survival and recapture probabilities \\
\hline
\end{tabular}

Notes: For each model, we give the number of estimable parameters $\left(n_{\mathrm{p}}\right)$, deviance (DEV), and the Akaike Information Criterion (AIC). Model notation is according to Lebreton et al. (1992). Boldface denotes the provisionally selected model.

tained the model $\left(\phi_{m+s 0+b 2}, p_{t}\right)$ as the more parsimonious model, which better described our data on Black-legged Kittiwakes at the study colony. That is, we conclude that variation in survival rate of breeding kittiwakes was due to mortality, permanent dispersal, or failure of surviving birds to attempt breeding in subsequent years. Under this model, survival probability varied greatly with year, between 0.53 and 0.98 (Fig. 1). Recapture probabilities did not depend on recapture effort; they were not different between sexes, but varied greatly with year (Fig. 1).

To estimate the survival probability for the period 1987-1988 $\left(\phi_{88}\right)$, we used the values of the environmental variables, entering the finally selected model for that year and using the coefficients of the logit link function of the finally selected model (shown in Table 6 ). Because we did not have any measure of the mean body mass of adults at the end of the breeding season of 1988 (see Table 2), we took the average value of that variable for the rest of the years. An average survival estimate for the whole period was calculated using the geometric mean of survival estimates following Cormack (1964): $0.801 \pm 0.028$ (mean $\pm 1 \mathrm{SD}$ ), calculated through the delta method (Seber 1982, Oro and Pradel 2000).

\section{Discussion}

Life history theory predicts that selection should favor allocation of time and resources toward the stage of the life history at which survival or reproduction is least variable, all other things being equal (Stearns 1992). In long-lived birds such as seabirds, survival of offspring is commonly variable and unpredictable, and selection should weight adult survival more heavily than fecundity (e.g., Goodman 1974, Charlesworth 1980). Several studies have shown that adult survival in many species of seabirds, including Black-legged Kittiwakes, is high and rather constant (e.g., Weimer- skirch et al. 1987, Aebischer and Coulson 1990, Hatch et al. 1993, Erikstad et al. 1995, Pugesek et al. 1995, Cam et al. 1998, Frederiksen and Petersen 1999), although adverse environmental conditions can decrease survival in specific years (e.g., Rattiste and Lilleleht 1995, Harris et al. 1997, Oro et al. 1999). Adult survival rate of breeding Black-legged Kittiwakes in Shetland shows a high variation, from 0.53 to 0.98 for both males and females, even higher than that recorded for the Antarctic Snow Petrel Pagodroma nivea, a seabird that breeds in extreme environmental conditions and shows high annual variability in survival and fecundity (Chastel et al. 1993). Our results contradict the concept of the "typical" seabird as having consistently high adult survival and strong buffering against environmental stress through variation in reproductive effort (Lindén and Møller 1989, Monaghan et al. 1989, Sæther et al. 1993, Oro et al. 1999). In fact, our models indicate that much of the variation in adult survival rates can be attributed to measured environmental factors. Adult survival rate was higher in years when adult body mass toward the end of the breeding season was high, and when 0-group sandeel abundance was high, as shown by both simple regression analysis (Fig. 2) and our models. Our models also indicated a weak effect of Great Skua breeding success, after taking account of the strong effects of adult body mass and 0group sandeel abundance; kittiwake survival showed a slight, but significant, decrease with increasing skua productivity (Table 6). When most of these environmental conditions coincided in a very bad year, adult survival was extremely low, as recorded in 1991 (see Fig. 1). Variations in environmental parameters have been exceptionally high during the study period, with unprecedented decrease in sandeel abundance causing fishery closure and widespread conservation concern. Such variability may be greater than that found in most marine environments studied, so that environmental in- 
TABLE 5. Influence of environmental factors on Black-legged Kittiwake survival.

\begin{tabular}{|c|c|c|c|c|}
\hline Model & $n_{\mathrm{p}}$ & DEV & AIC & Hypothesis tested on survival \\
\hline $\begin{array}{l}\left(\phi_{s+m+s 0+s 1+}\right. \\
k 1+k 2+b 1+b 2 \\
\left(p_{t}\right)\end{array}$ & 19 & 1571.2 & 1609.2 & $\begin{array}{l}\text { Effects of sex, mean mass of adults, sandeel availability (both } 0 \text { - and } \\
1+\text { groups), breeding success of kittiwakes at the colony and in } \\
\text { Shetland, percentage of sandeel in Great Skua chick regurgitates, } \\
\text { and breeding success of skuas at Foula }\end{array}$ \\
\hline $\begin{array}{r}\left(\phi_{m+s 0+s 1+k 1+}\right. \\
\left.k 2+b 1+b 2, p_{t}\right)\end{array}$ & 18 & 1572.0 & 1608.0 & $\begin{array}{l}\text { Effects of the mean mass of adults, sandeel availability (both } 0 \text { - and } \\
1+\text { groups), breeding success of kittiwakes at the colony and in } \\
\text { Shetland, percentage of sandeel in skua chick regurgitates and } \\
\text { breeding success of skuas at Foula }\end{array}$ \\
\hline $\begin{array}{l}\left(\phi_{m+s 0+s 1+k 1+b 2}\right. \\
\left.\quad p_{t}\right)\end{array}$ & 16 & 1572.0 & 1604.0 & $\begin{array}{l}\text { Effects of the mean mass of adults, sandeel availability (both } 0 \text { - and } \\
1+\text { groups), breeding success of kittiwakes at the colony and in } \\
\text { Shetland, and breeding success of Great Skuas at Foula }\end{array}$ \\
\hline$\left(\phi_{m+s 0+s 1+k 1}, p_{t}\right)$ & 14 & 1576.0 & 1604.0 & $\begin{array}{l}\text { Effects of the mean mass of adults, sandeel availability (both } 0 \text { - and } \\
1+\text { groups), and breeding success of kittiwakes at the colony }\end{array}$ \\
\hline$\left(\phi_{m+s 1+b 2}, p_{t}\right)$ & 14 & 1580.1 & 1608.1 & $\begin{array}{l}\text { Effects of the mean mass of adults, } 1+\text { sandeel availability, and } \\
\text { breeding success of Great Skuas at Foula }\end{array}$ \\
\hline$\left(\phi_{m+s 0+s 1+b 2}, p_{t}\right)$ & 14 & 1576.2 & 1604.2 & $\begin{array}{l}\text { Effects of the mean mass of adults, sandeel availability (both } 0 \text { - and } \\
1+\text { groups), and breeding success of Great Skuas at Foula }\end{array}$ \\
\hline$\left(\phi_{m+s 0+k 1+b 2}, p_{t}\right)$ & 14 & 1576.4 & 1604.4 & $\begin{array}{l}\text { Effects of the mean mass of adults, 0-group sandeel availability, } \\
\text { breeding success of kittiwakes at the colony, and breeding success } \\
\text { of Great Skuas at Foula }\end{array}$ \\
\hline$\left(\phi_{m+s 0+b 1}, p_{t}\right)$ & 14 & 1574.9 & 1602.9 & $\begin{array}{l}\text { Effects of the mean body mass of adults, 0-group sandeel availabili- } \\
\text { ty, and percentage of sandeel in Great Skua chick regurgitates }\end{array}$ \\
\hline$\left(\phi_{m+s 0+k 2+b 2}, p_{t}\right)$ & 14 & 1576.1 & 1604.1 & $\begin{array}{l}\text { Effects of the mean mass of adults, } 0 \text {-group sandeel availability, } \\
\text { breeding success of kittiwakes in Shetland, and breeding success } \\
\text { of Great Skuas at Foula }\end{array}$ \\
\hline$\left(\phi_{m+s 0+b 2}, p_{t}\right)$ & 13 & 1576.4 & 1602.4 & $\begin{array}{l}\text { Effects of the mean mass of adults, 0-group sandeel availability, } \\
\text { and breeding success of Great Skuas at Foula }\end{array}$ \\
\hline$\left(\phi_{m+s 0}, p_{t}\right)$ & 12 & 1585.9 & 1609.9 & Effects of the mean mass of adults, and 0 -group sandeel availability \\
\hline$\left(\phi_{s 0+b 2}, p_{t}\right)$ & 12 & 1583.1 & 1607.1 & $\begin{array}{l}\text { Effects of } 0 \text {-group sandeel availability and breeding success of Great } \\
\text { Skuas at Foula }\end{array}$ \\
\hline$\left(\phi_{m+s 1+k 1}, p_{t}\right)$ & 13 & 1585.8 & 1611.8 & $\begin{array}{l}\text { Effects of the mean mass of adults, } 1+\text { sandeel availability, and } \\
\text { breeding success of kittiwakes at the colony }\end{array}$ \\
\hline$\left(\phi_{m+k 1}, p_{t}\right)$ & 12 & 1586.0 & 1610.0 & $\begin{array}{l}\text { Effects of the mean mass of adults, and breeding success of kitti- } \\
\text { wakes at the colony }\end{array}$ \\
\hline$\left(\phi_{s 0}, p_{t}\right)$ & 11 & 1587.6 & 1609.6 & Effect of 0 -group sandeel availability \\
\hline$\left(\phi_{s 1}, p_{t}\right)$ & 11 & 1594.4 & 1616.4 & Effect of $1+$ group sandeel availability \\
\hline$\left(\phi_{b 2}, p_{t}\right)$ & 11 & 1592.5 & 1614.5 & Effect of the breeding success of Great Skuas at Foula \\
\hline$\left(\phi_{k 1}, p_{t}\right)$ & 11 & 1594.4 & 1616.4 & Effect of the breeding success of kittiwakes at the colony \\
\hline$\left(\phi_{m}, p_{t}\right)$ & 11 & 1586.7 & 1608.7 & Effect of the mean mass of adults \\
\hline
\end{tabular}

Notes: The factors considered were: $\operatorname{sex}(s)$; mean body mass of adults at the end of the breeding season $(\mathrm{m})$; sandeel availability (either 0-group $(s 0)$ or $1+$ group $(s 1)$ ); breeding success of Black-legged Kittiwakes at the colony $(k 1)$ and in Shetland $(k 2)$; percentage of sandeel in Great Skua chick regurgitates $(b 1)$; and breeding success of the Great Skuas at Foula (b2). Recapture probabilities depended only on time. The model with the lowest AIC is the best compromise between parsimony and description of the data (boldface model). The notation is the same as in Table 4.

fluences on demography often may be more difficult to detect. We explore the implications of the relationships in the following subsections.

\section{Effect of body condition on survival}

Adult survival rate of Black-legged Kittiwakes in our study was higher in years when breeding adults were heavier toward the end of the breeding season (Fig. 2). It has been suggested that a primary cause of adult mortality in gulls may be the loss of body mass (body condition) as the breeding season progresses (Coulson et al. 1983, Pugesek 1987, 1990). However, few studies have assessed properly the relationship of costs of reproduction to adult survival in gulls, and their results are controversial (Reid 1987, Pugesek and Diem 1990, Cam et al. 1998, Golet et al. 1998). Our results are consistent with the recent studies of Golet
TABLE 6. Maximum likelihood estimates (with $95 \%$ confidence intervals, $\mathrm{CI}$ ) of the factors affecting survival of Black-legged Kittiwakes from the model $\left(\phi_{m+s 0+b 2}, p_{t}\right)$.

\begin{tabular}{ccl}
\hline \hline $\begin{array}{c}\text { Coeffi- } \\
\text { cients } \dagger\end{array}$ & Estimate & \multicolumn{1}{c}{$95 \%$ CI } \\
\hline$a_{0}$ & -13.054 & $(-13.045,-13.065)$ \\
$a_{1}$ & 0.038 & $(+0.036,+0.040)$ \\
$a_{2}$ & 0.0028 & $(+0.0013,+0.0043)$ \\
$a_{3}$ & -0.4126 & $(-0.4215,-0.4127)$ \\
\hline
\end{tabular}

$\dagger$ The coefficients $\left(a_{0}, a_{1}\right)$ correspond to the logit function linking the parameters (survival, body mass of adults, $m$; 0 group sandeel availability $s 0$ and Great Skua productivity $b 2$ ) to a linear formula as $\phi_{t}=a_{0}+a_{1} m+a_{2} s 0+a_{3} b 2$. 
TABLE 7. Modeling survival probabilities of Black-legged Kittiwakes introducing the sex $(s)$, as a covariate from the previously selected model $\left(\phi_{m+50+b 2}, p_{t}\right.$; see Results), which still was the model with the lowest AIC (indicated in boldface); notation is as in Table 4 .

\begin{tabular}{|c|c|c|c|c|}
\hline Model & $n_{\mathrm{p}}$ & DEV & AIC & Hypothesis tested on survival \\
\hline$\left(\phi_{m+s 0+b 2}, p_{t}\right)$ & 13 & 1576.4 & 1602.4 & $\begin{array}{l}\text { Effects of the mean mass of adults, 0-group sandeel availability, } \\
\text { and breeding success of Great Skuas at Foula }\end{array}$ \\
\hline$\left(\phi_{\mathrm{s}^{*}(m+s 0+b 2)}, p_{t}\right)$ & 20 & 1564.4 & 1604.4 & $\begin{array}{l}\text { Effects of the mean mass of adults, 0-group sandeel availability, and } \\
\text { breeding success of Great Skuas at Foula different for each sex }\end{array}$ \\
\hline$\left(\phi_{\mathrm{s}^{*} m+s 0+b 2}, p_{t}\right)$ & 14 & 1575.8 & 1603.8 & $\begin{array}{l}\text { Effects of the interaction between mean adult mass and sex, with an } \\
\text { additive effect of } 0 \text {-group sandeel availability and breeding success } \\
\text { of Great Skuas }\end{array}$ \\
\hline$\left(\phi_{m+\mathrm{s}^{*} \mathrm{~s} 0+b 2}, p_{t}\right)$ & 15 & 1576.3 & 1606.3 & $\begin{array}{l}\text { Effects of the interaction between } 0 \text {-group sandeel availability and } \\
\text { sex, with an additive effect of the mean mass of adults and breed- } \\
\text { ing success of Great Skuas }\end{array}$ \\
\hline$\left(\phi_{m+s 0+s^{*} b 2}, p_{t}\right)$ & 14 & 1576.2 & 1604.3 & $\begin{array}{l}\text { Effects of the interaction between breeding success of Great Skuas } \\
\text { and sex, with an additive effect of the mean mass of adults and 0- } \\
\text { group sandeel availability }\end{array}$ \\
\hline
\end{tabular}

et al. (1998) and Golet and Irons (1999), which showed that chick rearing caused a reduction in body condition and fat stores of breeding kittiwakes and led to a lower adult survival rate than in birds for which reproductive effort was experimentally reduced by removing their chicks. Other possible hypotheses, such as intermittent breeding (i.e., nonbreeding in individuals that previously bred) or temporary emigration (i.e., individuals moving to another colony to breed) after an adverse breeding season (e.g., Thomas and Coulson 1988, Pyle et al. 1997, Cam et al. 1998, Oro et al. 1999, Oro and Pradel 2000), did not seem to fit our.results from the estimated recapture probabilities. Rather, the finally selected model suggests that breeding Black-legged Kittiwakes in Shetland are paying a cost of reproduction in terms of survival, and that adverse environmental conditions have increased these costs since the late 1980 s, coinciding with the decline of sandeel availability.

\section{Effect of food abundance on adult survival rate}

It is well known that, when availability of food during breeding and especially during chick rearing is low, kittiwakes may fail to breed successfully because they are beyond the limits of their buffering capacity (Walsh et al. 1991, Danchin 1992, Hamer et al. 1993). However, accurate measures of food availability and their inter-year variations are very difficult to obtain in natural conditions, and the influence of this environmental factor on adult survival is difficult to test. Of the two published studies on the effects of food availability on adult gull survival (Pons and Migot 1995, Oro et al.

TABLE 8. Introduction of the effects of the body mass of adults $(m), 0$-group sandeel availability $(s 0)$, and Great Skua productivity $(b 2)$ in both survival and recapture modeling, in comparison with the previously retained model $\left(\phi_{m+s 0+b 2}, p_{t}\right)$; notation is as in Table 4.

\begin{tabular}{|c|c|c|c|c|}
\hline Model & $n_{\mathrm{p}}$ & DEV & AIC & Hypothesis tested \\
\hline$\left(\phi_{m+s 0+b 2}, p_{t}\right)$ & 13 & 1576.4 & 1602.4 & $\begin{array}{l}\text { Effects of the mean mass of adults, 0-group sandeel availability, } \\
\text { and breeding success of Great Skuas on Black-legged Kittiwake } \\
\text { survival; effect of time on recapture rate }\end{array}$ \\
\hline$\left(\phi_{t}, p_{m+s 0+b 2}\right)$ & 11 & 1621.5 & 1643.5 & $\begin{array}{l}\text { Effect of time on survival; effects of the mean mass of adults, } 0 \text { - } \\
\text { group sandeel availability, and breeding success of Great Skuas on } \\
\text { recapture rate }\end{array}$ \\
\hline $\begin{array}{c}\left(\phi_{m+s 0+b 2}\right. \\
\left.\quad p_{m+50+b 2}\right)\end{array}$ & 7 & 1639.1 & 1653.1 & $\begin{array}{l}\text { Effects of the mean mass of adults, } 0 \text {-group sandeel availability, and } \\
\text { breeding success of Great Skuas on both survival and recapture } \\
\text { rates }\end{array}$ \\
\hline$\left(\phi, p_{m+s 0+b 2}\right)$ & 5 & 1681.8 & 1691.8 & $\begin{array}{l}\text { Constant survival; effects of the mean mass of adults, } 0 \text {-group sand- } \\
\text { eel availability, and breeding success of Great Skuas on recapture } \\
\text { rate }\end{array}$ \\
\hline$\left(\phi_{s 0+b 2}, p_{m}\right)$ & 5 & 1676.1 & 1686.1 & $\begin{array}{l}\text { Effects of } 0 \text {-group sandeel availability and breeding success of Great } \\
\text { Skuas on survival; effect of the mean mass of adults on recapture } \\
\text { rates }\end{array}$ \\
\hline$\left(\phi_{b 2}, p_{s 0+m}\right)$ & 5 & 1676.9 & 1686.9 & $\begin{array}{l}\text { Effects of breeding success of Great Skuas on survival; effects of } 0 \text { - } \\
\text { group sandeel availability and the mean mass of adults on recap- } \\
\text { ture rates }\end{array}$ \\
\hline$\left(\phi_{m+s 0}, p_{b 2}\right)$ & 4 & 1669.2 & 1677.2 & $\begin{array}{l}\text { Effects of the mean mass of adults and } 0 \text {-group sandeel availability } \\
\text { on survival; effect of breeding success of Great Skuas on recapture } \\
\text { rates }\end{array}$ \\
\hline
\end{tabular}



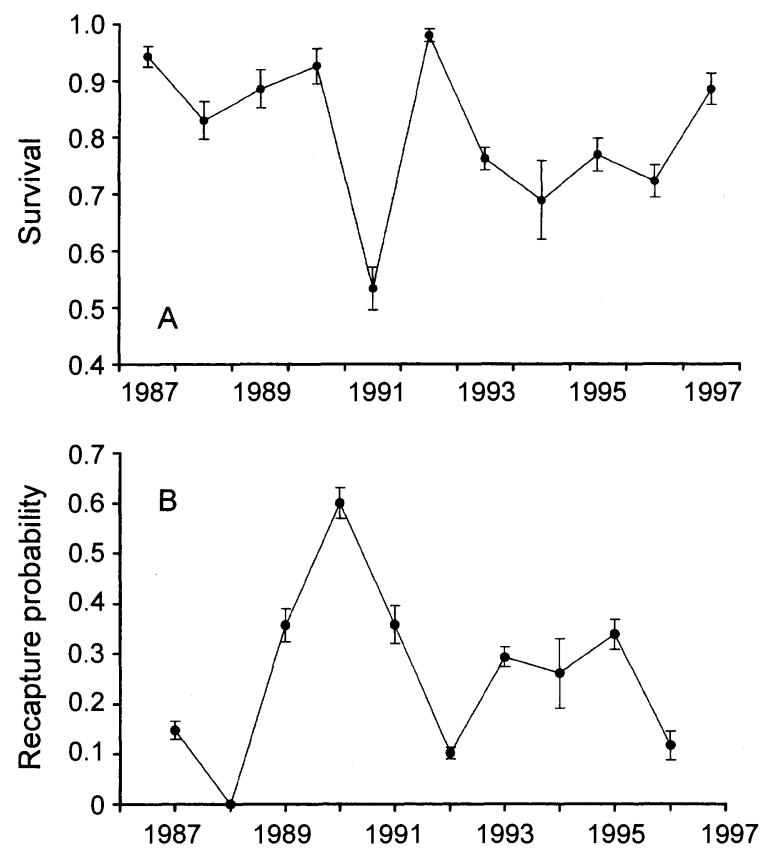

FIG. 1. Yearly estimates (mean $\pm 1 \mathrm{SD}$ ) of (A) adult survival and (B) recapture rates of Black-legged Kittiwakes breeding at Foula (Shetland) under the finally selected model $\left(\phi_{m+s 0+b 2}, p_{t}\right)$ (see Results).

1999), neither reported any relationship between the two parameters. However, our results show that adult survival of Black-legged Kittiwakes in Shetland was significantly correlated with the abundance of 0-group sandeels (Fig. 2), although it was independent of $1+$ group sandeel abundance. There is a negative correlation between 0 -group recruitment and $1+$ group abundance of sandeels in the large North Sea stock, but no significant correlation between 0 -group recruitment and $1+$ abundance in the Shetland stock (Furness 1999). Kittiwake breeding success in Shetland correlates with $1+$ sandeel abundance and is independent of 0-group abundance, the opposite of the relationship for adult survival. However, these contrasts are not unexpected. The 0-group sandeels do not recruit until midsummer, but remain available to kittiwakes during July and August, when $1+$ sandeels tend to remain buried in the sand and so have become unavailable to surface-feeding seabirds. Results suggest that 0-group sandeels probably play an important role for adult kittiwakes in replenishing body reserves depleted during breeding. Thus, adult kittiwake survival would depend not only on the environmental conditions during breeding and the reproductive effort associated, but also on those occurring just after breeding. In fact, several studies have shown that adult mortality of kittiwakes, and of gulls in general, probably occurs mostly after the breeding season (Coulson and Wooller 1976, Pugesek 1987, Reid 1987, Pugesek et al. 1995, Rattiste and Lilleleht 1995). Conversely, abundance of $1+$ sandeels, which are the main food of breeding kittiwakes from
April to June, affects breeding success of kittiwakes, but 0-group sandeels apparently recruit too late to do so even though they are fed to chicks (Galbraith 1983, Harris and Wanless 1990, 1997, Furness 1999).

\section{Effect of predation on adult survival rate}

After accounting for the influences of adult mass and sandeel abundance, kittiwake survival rate was slightly reduced in years when Great Skua breeding success was high. Most predation of kittiwakes by Great Skuas occurs when skuas have chicks to feed (Furness 1987, Hamer et al. 1991, Phillips et al. 1999), and it is therefore not surprising that the survival rate of adult kittiwakes was reduced in years when skuas had more chicks. There is a strong correlation between the percentage of sandeel in skua chick regurgitates and kittiwake productivity (Table 3 ). Sandeel availability was low for skuas during the whole study period, but when it was extremely low, breeding failure occurred. During years of Great Skua reproductive failure, the food requirements of the skua population would be much smaller because some birds that failed early would have dispersed, and others would remain relatively inactive in the territory (Hamer et al. 1991, Ratcliffe and Furness 1999). In contrast, when breeding success of skuas was higher because sandeel abundance was moderate, the extent of predation on kittiwakes would have been increased to meet the energy demand (Heubeck et al. 1997, 1999, Ratcliffe et al. 1998). If sandeel abundance were to return to the high levels prevailing in the 1970s (Furness 1987), we would anticipate a low level of

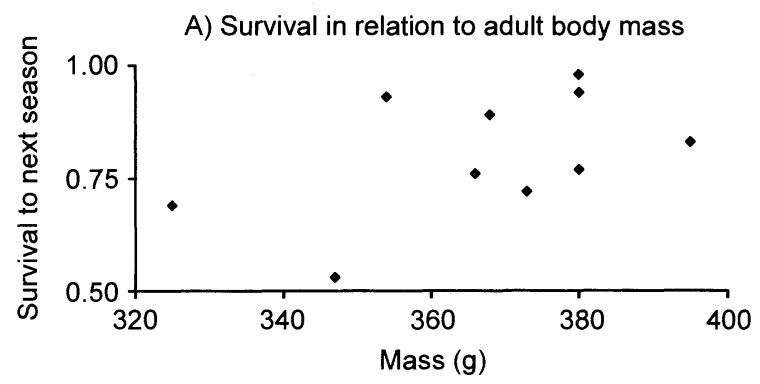

B) Survival in relation to 0-group sandeel abundance

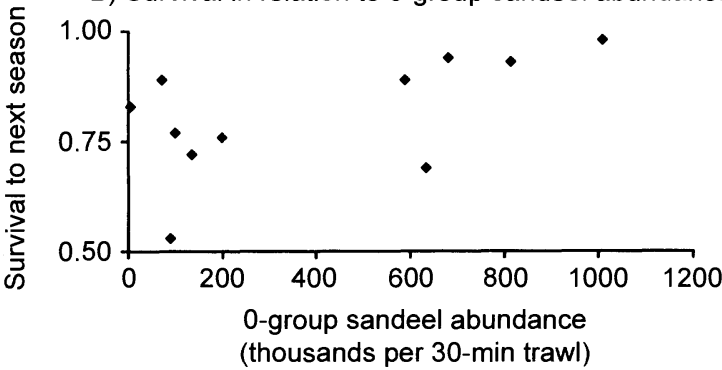

FIG. 2. Effects of (A) body mass and (B) Shetland sandeel catch of 0-group fish per 30-min tow on annual adult survival of Black-legged Kittiwakes at Foula (in Fig. 3A, data for 1988 were excluded due to lack of body mass measurements in that year). 
predation by skuas on kittiwakes despite high skua breeding success, because the skuas would be able to meet their requirements easily by feeding predominantly on sandeels.

\section{Why do Black-legged Kittiwakes not refrain from breeding when conditions are poor?}

Given that reproductive investment in years of poor 0 -group sandeel recruitment considerably reduces adult survival rate, life history theory would predict that kittiwakes would refrain from breeding in such years to avoid these costs. Nonbreeding is a common response to food shortage in Arctic Terns (Monaghan et al. 1992) and in jaegers breeding on Arctic tundra (Furness 1987), but is rare in many seabirds, including Great Skuas and Parasitic Jaegers Stercorarius parasiticus during the years of sandeel shortage in Shetland (Catry et al. 1998). Cam et al. (1998) concluded that the (relatively few) nonbreeding kittiwakes were predominantly poor-quality individuals rather than prudent parents, and our data from Foula provide no evidence that kittiwakes chose not to breed in years when conditions were poor. The failure of kittiwakes to avoid increased mortality in poor years suggests that birds in Shetland decided to breed even when environmental conditions were very adverse. This would be especially true if the frequency of nonbreeding kittiwakes at Foula were as low as in other populations (Cam et al. 1998). Kittiwakes breeding in that region were probably unable to predict during spring whether or not a particular season would be bad for their survival. This would be consistent with their survival being determined predominantly by 0 -group recruitment of sandeels, because the magnitude of sandeel recruitment in Shetland appears to be highly variable but unpredictable (Bailey et al. 1991, Wright and Bailey 1996, ICES 1997, 1998). However, we have to take into account that, in our study, we caught only birds with chicks at nest; this method probably biased results toward high-quality birds that attempted breeding under most environmental conditions (see also Cam et al. 1998).

\section{Survival estimates of Black-legged Kittiwakes at Foula and other colonies}

Our average estimate of adult survival of Black-legged Kittiwakes in Shetland is among the lowest recorded in Atlantic colonies (Aebischer and Coulson 1990, Danchin and Monnat 1992, Harris and Calladine 1993, Erikstad et al. 1995, Fairweather and Coulson 1995, Jacobsen et al. 1995, Coulson and Strowger 1999) and supports the view that adult survival in this region is significantly lower than that in Pacific colonies (Golet et al. 1998). On the other hand, mean productivity of kittiwakes at Foula was higher during the study $(0.74 \pm 0.39$ chicks per pair, mean $\pm 1 \mathrm{SD})$ than is usually found in Pacific colonies (Hatch et al. 1993, Erikstad et al. 1995). The differences in the trade-off between survival and reproduction in North Atlantic vs. North Pacific Black-legged Kittiwakes (those breeding in the eastern North Atlantic probably investing more in reproduction) suggest that life history traits may vary not only among related species, but also within a species in different geographical regions with different environmental conditions (e.g., Montevecchi et al. 1992, Oro et al. 1996).

\section{Implications for fisheries management and conservation science}

Our results have implications for fisheries management and conservation policy. It generally has been assumed that effects of fisheries that may reduce food supply to seabirds would impact seabird populations through reductions in breeding success, and that impacts on adult survival rate would be likely only if there were a major collapse of the food fish stock (Furness and Ainley 1984, Cairns 1987, Montevecchi 1993, Furness and Tasker 1997, Oro et al. 1999). However, although most North Atlantic seabird species feed mainly on fish, the effects of a reduction in fish availability do not affect all species equally. For instance, fluctuations in food availability would affect surface feeders, e.g., terns and gulls, more than divers, e.g., shearwaters and cormorants (Furness and Tasker 2000). Monitoring of seabirds in Britain and Ireland, which is as detailed as anywhere, has been based on a complete census of breeding populations at intervals of several years, annual monitoring of breeding numbers on defined study plots, and annual monitoring of breeding success (Thompson et al. 1998). However, there are very few studies of annual variations in adult survival rates or of net migration rates between local populations within a metapopulation (e.g., Spendelow et al. 1995). There is a need to monitor seabird adult survival rates as well as numbers and breeding success, and to develop management and precautionary strategies for industrial fisheries to avoid impacts on the most vulnerable species (birds, fish, and mammals). This distinction is important, because conserving $1+$ sandeels would protect the breeding success of kittiwakes, whereas to protect survival rates, 0-group sandeel abundance would need to be conserved. To a considerable extent, the industrial fishery harvests these two groups of fish in different seasons, sequentially taking older fish in spring to midsummer and 0-group fish from midsummer to autumn, so that seasonality of the fishery will affect its potential impact on different aspects of kittiwake life history.

\section{ACKNOWLEDGMENTS}

R. W. Furness was funded by IFOMA (International Fishmeal and Oil Manufacturers Association). Fieldwork at Foula was supported by NERC (Natural Environment Research Council) and SOTEAG (Shetland Oil Terminal Environmental Advisory Group). We thank the Holbourn family for permission to work in Foula. D. Oro was funded by the Spanish Ministerio de Educación y Ciencia (grant number EX 97 35056326). We are grateful to John Coulson, Jeff Walters, 
Bruce Pugesek, Bill Montevecchi, and an anonymous referee for helpful comments on the manuscript.

\section{Literature Cited}

Aebischer, N. J., and J. C. Coulson. 1990. Survival of the kittiwake in relation to sex, year, breeding experience and position in the colony. Journal of Animal Ecology 59:10631071.

Anderson, D. R., K. P. Burnham, and G. C. White. 1994. AIC model selection in overdispersed capture-recapture data. Ecology 75:1780-1793.

Bailey, R. S., R. W. Furness, J. A. Gauld, and P. A. Kunzlik 1991. Recent changes in the population of the sandeel ( $\mathrm{Am}$ modytes marinus Raitt) at Shetland in relation to estimates of seabird predation. ICES (International Council for the Exploration of the Sea) Marine Science Symposia 193:209_ 216.

$\rightarrow$ Barrett, R. T., R. Fieler, T. Anker-Nilssen, and F. Rikardsen. 1985. Measurements and weight changes of Norwegian adult puffins Fratercula arctica and kittiwakes Rissa tridactyla during the breeding season. Ringing and Migration 6:102-112.

Boulinier, T., G. Sorci, J. Clobert, and E. Danchin. 1997. Ar experimental study of the costs of reproduction in the kittiwake Rissa tridactyla: comment. Ecology 78:1284-1287.

$\rightarrow$ Burnham, K. P., D. R. Anderson, and G. C. White. 1994 Evaluation of the Kullback-Leibler discrepancy for model selection in open population capture-recapture models. Biometrical Journal 36:299-315.

$\rightarrow$ Burnham, K. P., D. R. Anderson, and G. C. White. 1995 Selection among open population capture-recapture models when capture probabilities are heterogeneous. Journal of Applied Statistics 22:611-624.

Burnham, K. P., D. R. Anderson, G. C. White, C. Brownie, and K. H. Pollock. 1987. Design and analysis methods for fish survival experiments based on release-recapture American Fisheries Society Monograph 5. Bethesda, Maryland, USA.

Cairns, D. K. 1987. Seabirds as indicators of marine food supplies. Biological Oceanography 5:261-271.

Cam, E., J. E. Hines, J. Y. Monnat, J. D. Nichols, and E. Danchin. 1998. Are adult nonbreeders prudent parents? The kittiwake model. Ecology 79:2917-2930.

Catry, P., R. A. Phillips, K. C. Hamer, N. Ratcliffe, and R W. Furness. 1998. The incidence of nonbreeding by adul Great Skuas and Parasitic Jaegers from Foula, Shetland. Condor 100:448-455.

Charlesworth, B. 1980. Evolution in age-structured populations. Cambridge University Press, Cambridge, UK.

$\rightarrow$ Chastel, O., H. Weimerskirch, and P. Jouventin. 1993. Higl, annual variability in reproductive success and survival of an Antarctic seabird, the snow petrel Pagodroma nivea. Oecologia 94:278-285.

$\rightarrow$ Clobert, J. 1995. Capture-recapture and evolutionary ecology: a difficult wedding? Journal of Applied Statistics 22: 989-1008.

Cooch, E. G., R. Pradel, and N. Nur. 1996. A practical guide to mark-recapture analysis using SURGE. Centre d'Ecologie Fonctionnelle et Evolutive-CNRS, Montpellier. France.

Cormack, R. M. 1964. Estimates of survival from the sighting of marked animals. Biometrika 51:429-438.

Coulson, J. C., P. Monaghan, J. Butterfield, N. Duncan, C. Thomas, and C. Shedden. 1983. Seasonal changes in the herring gull in Britain: weight, moult, and mortality. Ardea 71:235-244.

Coulson, J. C., and J. Strowger. 1999. The annual mortality rate of black-legged kittiwakes in NE England from 195 to 1998 and a recent exceptionally high mortality. Waterbirds 22:3-13.

Coulson, J. C., and R. D. Wooller. 1976. Differential surviva $\rightarrow$ Harris, M. P., S. N. Freeman, S. Wanless, B. J. T. Morgan, rates among breeding kittiwake gulls Rissa tridactyla $(\mathrm{L}$. Journal of Animal Ecology 45:203-213.

Danchin, E. 1992. Food shortage as a factor in the 1988 kittiwake Rissa tridactyla breeding failure in Shetland. Ardea 80:93-98.

Danchin, E., and J. Y. Monnat. 1992. Population dynamic modelling of two neighbouring kittiwake Rissa tridactyla colonies. Ardea 80:171-180.

Erikstad, K. E., T. Tveraa, and R. T. Barrett. 1995. Adult survival and chick production in long-lived seabirds: a 5year study of the kittiwake Rissa tridactyla. Pages 471477 in H. R. Skjoldal, C. Hopkins, K. E. Erikstad, and H. P. Leinaas, editors. Ecology of fjords and coastal waters. Elsevier Science B.V., Amsterdam, The Netherlands.

Fairweather, J. A., and J. C. Coulson. 1995. The influence of forced site change on the dispersal and breeding of the Black-legged Kittiwake Rissa tridactyla. Colonial Waterbirds 18:30-40.

Frederiksen, M., and A. Petersen. 1999. Adult survival of the Black Guillemot in Iceland. Condor 101:589-597.

Furness, R. W. 1987. The skuas. T. and A. D. Poyser, Calton, UK.

Furness, R. W. 1990. A preliminary assessment of the quantities of Shetland sandeels taken by seabirds, seals, predatory fish and the industrial fishery in 1981-83. Ibis 132: 205-217.

Furness, R. W. 1999. Does harvesting a million metric tons of sand lance per year from the North Sea threaten seabird populations? Pages 407-424 in Ecosystem approaches for fisheries management. Alaska Sea Grant College Program AK-SG-99-01, Fairbanks, Alaska, USA.

Furness, R. W., and D. G. Ainley. 1984. Threats to seabird populations presented by commercial fisheries. ICBP Technical Publications Number 2:701-708.ICBP (International Council for Bird Protection), Cambridge, UK.

Furness, R. W., and P. Monaghan. 1987. Seabird ecology. Blackie, New York, New York, USA.

Furness, R. W., and M. L. Tasker. 1997. Seabird consumption in sand lance MSVPA models for the North Sea, and the impact of industrial fishing on seabird population dynamics. Pages 147-169 in Forage fishes in marine ecosystems. Alaska Sea Grant College Program Report Number 97-01.

Furness, R. W., and M. L. Tasker. 2000. Seabird-fishery interactions: quantifying the sensitivity of seabirds to reductions in sandeel abundance, and identification of key areas for sensitive seabirds in the North Sea. Marine Ecology Progress Series 202:253-264.

Galbraith, H. 1983. The diet and feeding ecology of breeding kittiwakes Rissa tridactyla. Bird Study 30:109-120.

Golet, G. H., and D. B. Irons. 1999. Raising young reduces body condition and fat stores in black-legged kittiwakes. Oecologia 120:530-538.

Golet, G. H., D. B. Irons, and J. A. Estes. 1998. Survival costs of chick rearing in black-legged kittiwakes. Journal of Animal Ecology 67:827-841.

Goodman, D. 1974. Natural selection and a cost ceiling on reproductive effort. American Naturalist 131:247-268.

Hamer, K. C., R. W. Furness, and R. W. G. Caldow. 1991. The effects of changes in food availability on the breeding ecology of great skuas Catharacta skua in Shetland. Journal of Zoology, London 223:175-188.

Hamer, K. C., P. Monaghan, J. D. Uttley, P. Walton, and M. D. Burns. 1993. The influence of food supply on the breeding ecology of kittiwakes Rissa tridactyla in Shetland. Ibis 135: 255-263.

Harris, M. P., and J. Calladine. 1993. A check on the efficiency of finding colour-ringed kittiwakes Rissa tridactyla. Ringing and Migration 14:113-116. University of Alaska, Fairbanks, Alaska, USA. 
and C. V. Wernham. 1997. Factors influencing the surviva $\rightarrow$ Oro, D., R. Pradel, and J.-D. Lebreton. 1999. The effects of of puffins Fratercula arctica at a North Sea colony over a 20-year period. Journal of Avian Biology 28:287-295.

Harris, M. P., and S. Wanless. 1990. Breeding success o $\rightarrow$ kittiwakes Rissa tridactyla in 1986-88: evidence for changing conditions in the northern North Sea. Journal of Applied Ecology 27:172-187.

Harris, M. P., and S. Wanless. 1997. Breeding success, diet, and brood neglect in the kittiwake (Rissa tridactyla) over an 11-year period. ICES (International Council for the Exploration of the Seas) Journal of Marine Science 54:615623.

$\rightarrow$ Hatch, S. A., B. D. Roberts, and B. S. Fadley. 1993. Adult survival of black-legged kittiwakes Rissa tridactyla in a Pacific colony. Ibis 135:247-254.

Heubeck, M., R. M. Mellor, and P. V. Harvey. 1997. Changes in the breeding distribution and numbers of kittiwakes Rissa tridactyla around Unst, Shetland and the presumed role of predation by great skuas Stercorarius skua. Seabird $19-$ 12-21.

$\rightarrow$ Heubeck, M., R. M. Mellor, P. V. Harvey, A. R. Mainwood, and R. Riddington. 1999. Estimating the population sizi and rate of decline of kittiwakes Rissa tridactyla breeding in Shetland, 1981-97. Bird Study 46:48-61.

ICES. 1997. Report of the Working Group on the Assessment of Demersal Stocks in the North Sea and Skaggerak. ICES CM1997/Assess:6, 633 pages, International Council for the Exploration of the Seas, Copenhagen, Denmark. nest predation and food availability on life history traits in Audouin's gull. Oecologia 118:438-445.

$\rightarrow$ Phillips, R. A., R. W. G. Caldow, and R. W. Furness. 1996. The influence of food availability on the breeding effort and reproductive success of Arctic Skuas Stercorarius parasiticus. Ibis 138:410-419.

Phillips, R. A., D. R. Thompson, and K. C. Hamer. 1999. The impact of great skua predation on seabird populations at St Kilda: a bioenergetics model. Journal of Applied Ecology 36:218-232.

Pons, J.-M., and P. Migot. 1995. Life-history strategy of the herring gull: changes in survival and fecundity in a population subjected to various feeding conditions. Journal of Animal Ecology 64:592-599.

Pradel, R., J. E. Hines, J.-D. Lebreton, and J. D. Nichols. 1997. Capture-recapture survival models taking account of transients. Biometrics 53:88-99.

Pugesek, B. H. 1987. Age-specific survivorship in relation to clutch size and fledging success in California gulls. Behavioral Ecology and Sociobiology 21:217-221.

Pugesek, B. H. 1990. Parental effort in the California Gull: tests of parent-offspring conflict theory. Behavioral Ecology and Sociobiology 27:211-215.

Pugesek, B. H., and K. L. Diem. 1990. The relationship between reproduction and survival in known-aged California gulls. Ecology 71:811-817.

ICES. 1998. Report of the Working Group on the Assessment of Demersal Stocks in the North Sea and Skaggerak. ICES CM1998/Assess: 7, 702 pages, International Council for th $\rightarrow$ Exploration of the Seas, Copenhagen, Denmark.

Jacobsen, K. O., K. E. Erikstad, and B. E. Sæther. 1995. An experimental study of the costs of reproduction in the Kit $\rightarrow$ tiwake (Rissa tridactyla). Ecology 76:1636-1642.

Lebreton, J.-D., K. P. Burnham, J. Clobert, and D. R. Anderson. 1992. Modeling survival and testing biological hypothesis using marked animals: a unified approach with case studies. Ecological Monographs 62:67-118.

$\rightarrow$ Lindén, M., and A. P. Møller. 1989. Cost of reproduction and covariation of life history traits in birds. Trends in Ecology and Evolution 4:367-371.

McCullagh, P., and J. A. Nelder. 1989, Generalized linear models. Chapman and Hall, New York, New York, USA.

$\rightarrow$ McNamara, J. M., and A. I. Houston. 1996. State-dependen $\rightarrow$ life histories. Nature 380:215-221.

Monaghan, P., J. D. Uttley, and M. D. Burns. 1992. Effects of changes in food availability on reproductive effort in Arctic terns. Ardea 80:71-81.

Monaghan, P., J. D. Uttley, M. D. Burns, C. Thaine, and J. Blackwood. 1989. The relationship between food supply, reproductive effort and breeding success in Arctic terns Sterna paradisaea. Journal of Animal Ecology 58:261-274.

Montevecchi, W. A. 1993. Birds as indicators of change in marine prey stocks. Pages 217-265 in R. W. Furness and J. J. D. Greenwood, editors. Birds as monitors of environmental change. Chapman and Hall, London, UK.

Montevecchi, W. A., V. L. Birt-Friesen, and D. K. Cairns. 1992. Reproductive energetics and prey harvest of Leach's Storm-Petrels in the northwest Atlantic. Ecology 73:823832 .

$\rightarrow$ Oro, D., X. Genovart, X. Ruiz, J. Jiménez, and J. GarciaGans. 1996. Differences in diet, population increase and breeding performance between two colonies of Audouin's Gulls Larus audouinii during breeding seasons affected by a trawling moratorium. Journal of Avian Biology 27:245251.

Oro, D., and R. Pradel. 2000. Determinants of local recruitment in a growing colony of Audouin's gull. Journal of Animal Ecology 69:1-14.

$\rightarrow$ Pugesek, B. H., C. Nations, K. L. Diem, and R. Pradel. 1995. Mark-resightings analysis of a California gull population. Journal of Applied Statistics 22:625-639.

Pyle, P., N. Nur, W. J. Sydeman, and S. D. Emslie. 1997. Cost of reproduction and the evolution of deferred breeding in the western gull. Behavioral Ecology 8:140-147.

Ratcliffe, N., and R. W. Furness. 1999. The effect of parental age and experimentally manipulated brood size on the foraging effort and breeding performance of great skuas ( $\mathrm{Ca}$ tharacta skua). Journal of Zoology, London 249:195-201.

Ratcliffe, N., R. W. Furness, and K. C. Hamer. 1998. The interactive effects of age and food supply on the breeding ecology of great skuas. Journal of Animal Ecology 67:853862.

$\rightarrow$ Rattiste, K., and V. Lilleleht. 1995. Survival rates of breeding common gulls in Estonia. Journal of Applied Statistics 22: 1057-1062.

$\rightarrow$ Reid, W. V. 1987. The cost of reproduction in the Glaucouswinged gull. Oecologia 74:458-467.

Roff, D. A. 1992. The evolution of life histories: theory and analysis. Chapman and Hall, New York, New York, USA.

$\rightarrow$ Sæther, B.-E., R. Andersen, and H. C. Pedersen. 1993. Regulation of parental effort in a long-lived seabird: an experimental manipulation of the cost of reproduction in the antarctic petrel, Thalassoica antarctica. Behavioral Ecology and Sociobiology 33:147-150.

Seber, G. A. F. 1982. The estimation of animal abundance and related parameters. Macmillan, New York, New York, USA.

Sluys, R. 1982. Geographical variation of the kittiwake, Rissa tridactyla. Le Gerfaut 72:221-230.

Spendelow, J. A., J. D. Nichols, I. C. T. Nisbet, H. Hays, G. D. Cormons, J. Burger, C. Safina, J. E. Hines, and M. Gochfeld. 1995. Estimating annual survival and movement rates of adults within a metapopulation of Roseate Terns. Ecology 76:2415-2428.

Stearns, S. C. 1992. The evolution of life histories. Oxford University Press, New York, New York, USA.

Thomas, C. S., and J. C. Coulson. 1988. Reproductive success of kittiwake gulls, Rissa tridactyla. Pages 251-262 in T. H. Clutton-Brock, editor. Reproductive success. University of Chicago Press, Chicago, Illinois, USA.

Thompson, K. R., E. Brindley, and M. Heubeck. 1996. Sea- 
bird numbers and breeding success in Britain and Ireland, 1995. Joint Nature Conservation Committee, Peterborough, UK.

Thompson, K. R., E. Brindley, and M. Heubeck. 1997. Seabird numbers and breeding success in Britain and Ireland, 1996. Joint Nature Conservation Committee, Peterborough, UK.

Thompson, K. R., E. Brindley, and M. Heubeck. 1998. Seabird numbers and breeding success in Britain and Ireland, 1997. Joint Nature Conservation Committee, Peterborough, UK.

Walsh, P. M., E. Brindley, and M. Heubeck. 1994. Seabird numbers and breeding success in Britain and Ireland, 1993. Joint Nature Conservation Committee, Peterborough, UK.

Walsh, P. M., E. Brindley, and M. Heubeck. 1995a. Seabird numbers and breeding success in Britain and Ireland, 1994. Joint Nature Conservation Committee, Peterborough, UK. Walsh, P. M., D. J. Halley, M. P. Harris, A. del Nevo, I. M W. Sim, and M. L. Tasker. 1995b. Seabird monitoring handbook for Britain and Ireland. JNCC (Joint Nature Conservation Committee), RSPB (Royal Society for the Protection of Birds), ITE (Institute of Terrestrial Ecology), and Seabird Group, Peterborough, UK.

Walsh, P. M., J. Sears, and M. Heubeck. 1991. Seabird numbers and breeding success in 1990. Nature Conservancy Council, Peterborough, UK.

Walsh, P. M., I. Sim, and M. Heubeck. 1992. Seabird numbers and breeding success in Britain and Ireland, 1991. Joint Nature Conservation Committee, Peterborough, UK.

Walsh, P. M., I. Sim, and M. Heubeck. 1993. Seabird numbers and breeding success in Britain and Ireland, 1992. Joint Nature Conservation Committee, Peterborough, UK.

Weimerskirch, H., J. Clobert, and P. Jouventin. 1987. Survival in five southern albatrosses and its relationship with their life history. Journal of Animal Ecology 56:10431055.

Wernham, C. V., and D. M. Bryant. 1998. An experimental study of reduced parental effort and future reproductive success in the puffin Fratercula arctica. Journal of Animal Ecology 67:25-40

Wright, P. J., and M. C. Bailey. 1996. Timing of hatching in Ammodytes marinus from Shetland waters and its significance to early growth and survivorship. Marine Biology 126: $143-152$. 